\title{
Looking for Indigenous Entities in Afro-Brazilian Religions in Manaus: Activated Relations
}

\author{
Deise Lucy Oliveira Montardo \\ Universidade Federal do Amazonas, Brasil \& Instituto Nacional de Ciência e \\ Tecnologia, Brasil Plural (Cnpq/FAPEAM/FAPESC/CAPES)
}

etropic 14.2 (2015): 44-52. http://www.reefandleaf.com.au/etropic.html \& http://www.jcu.edu.au/etropic

\begin{abstract}
This text is an entrance to the universe of Afro-Brazilian religions, in a search for the references, presence and action of indigenous entities. The focus begins with Umbanda, in whose origin myth indigenous entities have a foundational and central role. This universe expands, however, to other religions, and the interest falls on dialogues that take place in the spiritual plane between beings and their performances in the rituals. The field study that informs this paper was conducted in Manaus because the city has a strong presence of AfroBrazilian religions and significant contingent indigenous populations - which awakens curiosity about how, and if, this interferes in the manifestation of the indigenous entities in the religious context.
\end{abstract}

\section{Looking for Indigenous Entities in Afro-Brazilian Religions in Manaus}

I begin this text ${ }^{1}$ expressing appreciation for the challenge placed before me by Barbara Glowczewski when she was with us at the graduate program in Anthropology at Universidade Federal do Amazonas (UFAM), in Manaus. Prior to Barbara's challenge, I had conducted extensive research about music and dance in the daily rituals of the Guarani Kaiová, an indigenous people of South America. Seven years ago I began to work as a professor and researcher at the Federal University at Amazonas, in Manaus, the capital of Amazonas state, a city of two million people with an enormous indigenous population, and where even people who do not recognize themselves to be indigenous have indigenous physiognomic traits. Afro-Brazilian religions have a strong presence in this city.

Barbara expressed her interest in visiting a terreiro, ${ }^{2}$ and I informed her that an

\footnotetext{
1 This text is based on a research which is part of the project "Art and Sociabilities on Amazon” financed by INCT Brasil Plural (Cnpq/FAPEAM/FAPESC/CAPES) and developed by the Research Group "Maracá: Studies about Arte, Cultura and Society” (UFAM).

${ }^{2}$ Terreiro is a term used for the place of the Umbanda and Candomblé cult and is usually located in the home of the pai de santo, the spiritual leader or director.
} 
undergraduate student, Ademir Souza Filho, was beginning a study about corporeal performance in Afro-Brazilian religions, and I had suggested focusing on indigenous entities. ${ }^{3}$ Barbara invited me to speak of this study at the colloquium of the TransOceanik International Associated Laboratory entitled: "Behind the Scenes: Emergence of Forms and Assemblages of Existence/ L'envers du décor: émergence des formes et agencements d'existence". The invitation to present was an adventure for me, because at that time this was still a new world being unveiled to me. Nevertheless, in some visits made to the festivities at the terreiro, I was able to witness the emergence of indigenous spirits and others that appear and interact among each other and with other participants. These spirits, which the natives call entities, are attracted by the beating of the drums and by the songs chanted and are incorporated in the initiates in rituals of possession.

The interest in the study arose from the desire to understand more about the presence of indigenous entities (spirits), or caboclos, ${ }^{4}$ in the Afro-Brazilian religions in Manaus. It is first important to emphasize that we are not the first to have tried to understand the presence of indigenous entities. Many before us have done so through various methods, in various regions of Brazil. Boyer (1999) for example, asks about the caboclo in religions in Belém, the capital of the neighboring state of Pará, where he conducted a deep exploration of the multiplicity of meanings of the word caboclo.

My approach to these issues is based on the statements of interlocutors, and begins with the interlocutor's speeches. The interest is not in classifying the religions, or in understanding if the practitioners are from one or another specific religion. Rather, my concern is in analysing the relations established between individuals and entities in the possession processes. In this paper I will discuss the explorations undertaken with my student Ademir Souza Filho in the final months of 2013 and early 2014.

\section{Beginning the Fieldwork}

When we began to ask about the indigenous entities, the interlocutors told us to go to Umbanda terreiros. We heard that Candomblé works with the orixás ${ }^{5}$ and Umbanda is dedicated to the caboclos. This distinction also appears with strong emphasis in the literature, as we will see below. With this information, and after visiting some Candomblé and Umbanda terreiros, Ademir began to frequent the The Rosa dos Ventos Universalist Umbanda Temple, an Umbanda terreiro, in the Alvorada II neighborhood, where he is conducting his study (Souza Filho \& Montardo, 2013).

In Umbanda, indigenous caboclos are from the line of Oxossi, orixá of the forests. Knowing that January is the sacred month for Oxossi or St Sebastião (his Catholic name), I invited Ademir Souza Filho to go to an Oxossi festival at the Candomblé terreiro of Pai ${ }^{6}$ Arllyson, in the São José neighborhood, in the eastern zone of Manaus. This is a terreiro, with precarious social conditions, that I had previously visited with friends from the Anthropology

\footnotetext{
${ }^{3}$ Entity is the term used by the practitioners of the Afro-Brazilian religions to speak of the spirits that are incorporated, in rituals of possession, and can be recognized as indigenous, Africans, mestizos and others.

${ }^{4}$ Caboclo or cabocla in the feminine, is an extremely polysemic term used to signify descendants of indigenous or mixed race people, residents of the interior and rural areas, indigenous entities in the Afro-Brazilian religions, and other definitions.

${ }^{5}$ Orixá is a generic designation of the divinities worshiped by the Yorubas, brought to Brazil by African slaves and incorporated here by Afro-Brazilian religions.

${ }^{6} \mathrm{Pai}$ [father] or pai de santo [father of the saint] is the leader of the terreiro.
} 
department. The festival, nearly three-hours long, was beautiful. A succession of entities danced to the sounds of the atabaques, ${ }^{7}$ two "filhos de santo" who were being initiated began to spin, an Exu and an $\mathrm{Ogum}^{8}$. The terreiro had just undergone some restoration and expansion and the festival was attended by various pais de santo, the father and grandfather of the santo ${ }^{9}$ of the owner of the house were also present and sang pontos. ${ }^{10}$ At the end, speaking with one of the saint-children of the house, I mentioned that our research interest was the caboclos, the indigenous. He immediately asked if I had been to a macumba of caboclos, and invited me to come back the next day when there would be a caboclo festival with the caboclo Jacaúna, the first entity he, Anderson, embodied when he was 16 years old.

The next day we arrived at one in the afternoon to drums already being played. We spent the entire afternoon dancing, talking and drinking with a variety of entities, who, one after the other, appeared in the body of their cavalos. ${ }^{11}$ Caboclo Jacaúna told us that he was a great chief, took us to see the offering that he and another cabocla, the sponsors of the festival, had made outside the covered portion of the terreiro. There were lots of fruits, corn, and in a large serving dish of pieces of chicken and traces of its blood. Anderson, the cavalo of Cacique Jacaúna, came about an hour later to receive the caboclo Basilio, an entity that liked alcohol and fun. A large number of indigenous caciques, caboclos and caboclas from the country of Turkey, and wandering caboclas, spent the afternoon interacting with each other and with the other participants of the festival. One entity embodied youth approached me and asked if I was married. When I said I was single, he asked me to marry him. I smiled and said that before marriage we would have to go out and get to know each other, he asked if I liked younger men, and I said yes. He then explained that the courtship would not be in bed, because he is a 16-year-old spirit, a cowboy from southern Brazil who was killed by his brother, the son of his father, the boss, and a slave. I present this narrative to highlight the interactivity between the entities and the other participants - in which a female researcher can even find a spirit boyfriend.

\footnotetext{
${ }^{7}$ The atabaques are a family of tall cone-shaped drums that have a special place in the terreiros and are played by the ogans, sons of the house who have this role in the cults.

${ }^{8}$ Exu and Ogun are orixás, gods, divinities of Candomblé.

${ }^{9}$ Pai de santo is the spiritual chief with whom the initiation was made, and from whom a family is created in the religion with children, uncles and aunts, and grandfather or grandmother.

${ }^{10}$ Pontos are the specific songs that are chanted for each entity, as a call or greeting.

${ }^{11}$ Cavalo (horse) is the name given to children (filho) of the saint when they are possessed by the entities. The entity, upon conversing, speaks of "his cavalo" in the third person. Such as: "my cavalo has such and such characteristics...”
} 

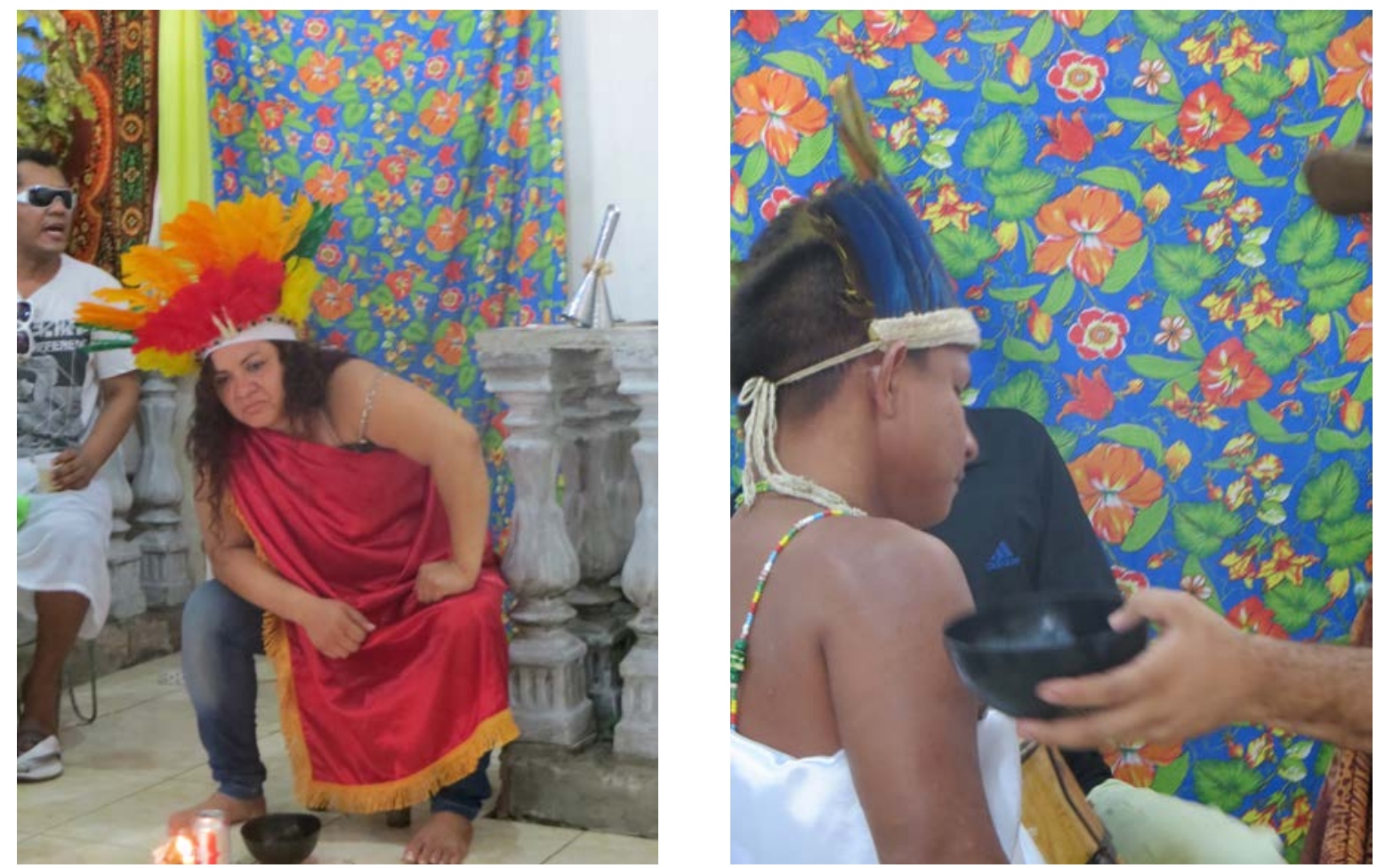

Festival of the caboclos at the Terreiro of father Arlysson. (Photos Deise Lucy Montardo, 19 January 2014, Manaus, Amazonia, Brazil.

\section{Researching the Literature}

Upon conducting a survey about the indigenous presence in the literature about AfroBrazilian religions, in both anthropology and history, and texts written by Umbanda and Candomblé authors, I noticed that the reference to indigenous entities is more frequent in those concerning Umbanda, Jurema and Pajelança, among others. The indigenous entities are at the core of the rise of Umbanda, in its founding myth. Prandi (2014) sketches an overview of the presence of caboclos in Afro-Brazilian religions related to Candomble of the Banto origin, which in Bahia had initiated the cult to the indigenous ancestors, which had been diffused therought Brazil, incorporating ancestral spirits with regional variations. ${ }^{12}$ According to Prandi (2014), with the arrival of Kardeckian Spiritism in Brazil, there was a large confluence between these religions and a unifying movement, thus creating Umbanda. During the 20th century, this movement won the battle over the legalisation of Afro-Brazilian religions, which were the object of prejudice and criminalisation. Prandi (2014) identifies that

${ }^{12}$ Oliveira, in his historic study about the rise of Umbanda, reports that the manifestation of the spirits of the blacks and indians, which is quite common in Umbanda, "takes place spontaneously in the Macumba rituals of the mid 18th century. Far from being an organized cult, Macumba was an aggregate of elements of the Cabula Bantu, of Candomblé jeje-nagô, of the indigenous traditions and of popular Catholicism, without the support of a doctrine that was capable of integrating the various pieces that gave it shape. It is this heterogeneous grouping, combined with elements that left Kardecism, which would give birth to a new religion. ” (2008, p.1) 
today there is great flexibility in the religious scenario, which allows the revision of these roles and highlights that this takes place in the trances.

Although they were legalized, these religious practices continue to suffer persecution. On the afternoon we spent at the terreiro, three times during the festival we heard the strong crash of stones being thrown on the roof. As I stated earlier, the terreiro of Pai Arlysson is located in a peripheral neighborhood of Manaus. This is a zone without sewerage, comprised of small lots where each house occupies nearly the entirely plot, and where the residents are very poor. The practitioners of Afro-Brazilian religions were persecuted and stigmatized during the first half of the $20^{\text {th }}$ century. Although there have not been any laws "that directly prohibit the practices of these cults since the first Republican Constitution of 1891” (Silva, 2011, p.3), people were condemned for illegal practice of medicine, and accused of witchcraft among other practices. In 1934, during the New State period, the police established a Toxics and Mystifications Division, which intensified the persecution. Among the various strategies used to confront this persecution, Silva (2011) notes the creation of civil entities and the conquest of the Religion Statute law. After a few decades of recognition of these practices by a portion of civil society, a resurgence in increased intolerance has been seen in recent years from the large number of converts to neo-Pentecostal religions. This persecution occurs in various forms whenever there is a meeting of the practitioners. For this reason, it has been strategically important for the Afro-Brazilian religions to come together to confront this opposition.

Ferreti (2011), in one of his texts about the Pajelança in Maranhão, refers to the persecution suffered by the pajés in the 1930s and 1940s and how this had led them to join the terreiros of Minas. There are many encantados (enchantments) ${ }^{13}$ - entities that did not die; they went to the bottom of the river or to the forest, without dying.

The literature about Afro-Brazilian religions is vast, there are records of a wide variety of nomenclatures, of various entities and regional specificities - as well as epistemological perspectives from which they were analyzed. There are perhaps more studies about Umbanda, conducted by academic researchers and by practitioners of religion. Umbanda is a paradigmatic case because the history told about its founding, the origin "myth" of this religion, dates to November 15, 1908, when during a mediumistic session at the Espírita center of Niterói (at the time the capital of Rio de Janeiro state), the spirit of the Caboclo of the Seven Crosses "possessed" the young Zélio de Moraes, the founder of the religion, who, since then, has hosted and exalted all the spirits of the Indians and blacks who until then had been refused and disdained in the Kardecian Spiritist centers (Chiasa, 2012, p. 233).

Historians present evidence of previous occasions of these mixed practices in various regions of Brazil, but Umbanda underwent a large movement of institutionalisation and it was effectively legalized as a religion. I will comment on the work of Chiesa (2012), because by narrating the spiritual religious trajectory of Pai Valdo, Chiesa unveils the communicability that exists between these worlds, passing through the same entities that surge and resurge in the life of the practitioners.

\footnotetext{
${ }^{13}$ In Brazil's North and Northeast regions these religions also have many encantados (the enchanted) which are entities of people who pass on to other planes without dying, they go to the bottom of the rivers or to the forest and are present in the rituals and even in some places in the daily life of the locations.
} 
Valdo, born in Salvador, worked as a Catholic priest in Rio de Janeiro, when he began to feel ill, and taking the advice of a member of the congregation, went to a terreiro on the day of the worship Yemanjá. The pai de santo received him with all honors and during the session when he incorporated the Caboclo Mata-Virgem, he approached the priest, slapped his head and the priest "blanked out" and incorporated the Caboclo de Aruanda for the first time. Chiasa (2012), continues to tell the trajectory of the life of Valdo, who over the years

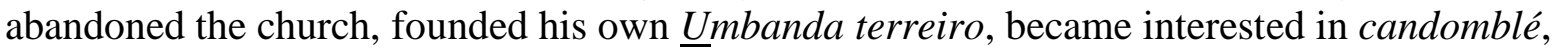
went to Bahia where he became initiated in Candomble and opened his own terreiro. In the continuity of his trajectory, and following his spiritual guide, the Caboclo Ventania de Aruanda, returned to Umbanda, and came to administer courses and publish texts in an effort to affirm this as "the sole truly Brazilian religion (and not Afro-Brazilian) and thus, capable of producing a sense and an image of what is Brazil - notably marked by the myth of the 'three races'- incorporating a 'Brazilian way' of being (and conducting religion) responsible for producing a specific reflection about the world, creating a world that wants to be genuinely Brazilian.” (Chiasa 2012: 232)

In Umbanda, in addition to the indigenous caboclos and the "preto-velhos" [old black men], other beings are present "that inhabit or inhabited the Northeastern sertão ("boiadeiros" or cowhands) the Brazilian coast ("marujos" or sailors) the largest cities and their streets or intersections ("exus" and "pombajiras") and the large houses typical of the colonial period (also inhabited by their "children”)". Chiasa recalled that these are beings that "dominate and knew very well the places that they inhabit” (2012, p. 233). The festival of the caboclo narrated above, which took place in the Candomblé terreiro in Manaus, whose lineage has a strong influence from Tambor de Mina and "encantaria", is frequented by more than one variety of beings. ${ }^{14}$

\section{Returning to the Caboclo House}

The festival of the caboclo described above ended at nearly $6 \mathrm{pm}$. Anderson, the sponsor of the festival, after the caboclo Basílio left him, said goodbye, commenting to the group of people around him, that he would learn the "route" in a few minutes. Route is the term used to refer to the buses and vans that cross the city transporting the workers in the Manaus Industrial District. He concluded saying that he can't lose this job, because this year he has obligations to the religion, and for this reason, needs his salary.

Our proposal upon entering this religious universe in Manaus was to hear what the practitioners of the religion tell us. What stood out is that it would not work to try to identify African and or indigenous traits or matrixes. In the universe of the spiritualist religions, it

\footnotetext{
${ }^{14}$ Pacheco, in his thesis about the Pajelança in Maranhão state, presents a typology of the encantados that descend in the terreiros of Tambor de Mina, emphasizing that there are many of them and that they belong to various categories. "There are the voduns and orixás, divinities of African origin, which come mainly from the pantheons of jeje (such as Badé and Averequete) and nagô (such as Iemanjá and Ogum) and are often syncretized with Catholic saints. There are the gentis, spirits of European nobles who may be associated to voduns and orixás and also to Catholic saints, such as King Sebastião, a very popular encantado associated to São Sebastião and also to the vodum Xapanã. There are the fidalgos or gentilheiros, organized in numerous families such as the Familia da Turquia or the Família da Bandeira. They are distinct from the orixás and at times confused with caboclos; and finally there are the caboclos, a category that encompasses various types of entities that arose in Brazil.” (2004:49)
} 
appears to me that at the time of the encounter, there is a translation of meanings and communication is established. In my research with the Kaiowá, my main interlocutor had on his altar crosses and a Buddha, which she said added strength to the Guarani elements. On the spiritual plane there is recognition and a dialogue among these subjects, objects and/or spirits.

Barbosa Neto (2012) in his work about the Batuque, a generic term used for Afro-Brazilian religions in Rio Grande do Sul state in southern Brazil, and the crossed line, a shape that is now commonly used by these religions in the state, presents a discussion that helps to consider the direction I would like this research to go. I highlight here four of his theoretical exploratory notes:

I use the term collective in the same sense given to it by Latour, which, in this case, supposes a complex distribution of agency among spirits, humans, animals and objects, but I also understand, now in the definition used by Deleuze and Guattari, that a collective is defined by a transversality, that is, by a mode, or various modes, of establishing the relationship between heterogeneous elements as heterogeneous elements. (Neto, 2012, p. 10)

Barbosa Neto also invites us to read the words of Anjos:

the rhyzomatic logic of Afro-Brazilian religiosity, instead of dissolving differences, connects the different to the different, allowing differences to exist as such. A caboclo remains different from an orixá even if worshipped in the same terreiro and under the same proper name (such as Ogum). (Anjos, 2008, quoted in Neto. 2012, p. 10)

Here is another inspirational quote noted by Barbosa Neto:

Bastide, during his study about the 'Catholic-fetishist syncretism' met the mãepequena ${ }^{15}$ [small-mother] of an 'ancient gege sanctuary, which has now disappeared, and who had entered an Angolan terreiro." She told him that the "spirit of Iansã and that of Santa Bárbara are absolutely the same spirit," but with "different names depending on the sects." And then he comments: "This is important, Catholicism is considered not as a religion that is totally different from other African religions but, in a certain way, as a nation, a type of tribal, ethnic culture" (Bastide, 1983, quoted in Neto, 2012, p. 17).

A fourth note:

I remember here what Mott wrote (1976: 1) based on his ethnography about $\underline{\text { Umbanda }}$ in the city of Marília. 'At the time [between 1966 and 1967], I was the only Japanese who frequented terreiros with a certain regularity and I often received invitations from chiefs of the terreiros to "become a medium", so that the terreiro could "receive" the "Japanese line" or the "line of Buddha" which he was sure was my line.' (Neto, 2012, PAGE NUMBER)

\footnotetext{
${ }^{15}$ Mãe Pequena, in Candomblé, is the second person in the house, in the absence of the Iyalorixá or Babalorixá she is the one who assumes command. She is always present and is part of all the precepts and obligations.
} 
What I intend to highlight with these notes is the translatability that takes place between the religious universes that are in contact with each other, whether they are indigenous, AfroBrazilian, Catholic, Evangelical or others. The terreiro of Rosa dos Ventos that is being studied by Souza Filho and Montardo (2013), in Manaus, for example, finds a translation between Umbanda, Jurema and the Fraternidade Branca de Saint Germain. Guimarães (2006) study in Rio de Janeiro also found this kind of relationship between a terreiro of Umbanda with Santo Daime.

In his book “Religião como Tradução,” [Religion as Translation] Pompa (2003) provides us with a deep analysis of two centuries of colonial encounters in Brazil. He shows that two cultural universes, that of indigenous groups and the missionary project, involved in an interplay caused by the colonial impact, "were not, however, irreducible polarities: from the first contacts, a common level was created (sought) a dimension of symbolic transit that had in the "religious" its language of mediation." (2003: 417). I think that this suggestion of translation can be useful for better understanding these religious encounters.

\section{Activated Relations}

To exemplify these notes, I will indicate a convergence and a difference that I find between these universes and that I believe deserves more study and reflection. My study with the Kaiowa indicated the central role played by the mbaraka, the rattle in Guarani shamanism (Montardo, 2009). When my interlocutor Dona Odúlia spoke of her initiation and her work she spoke of holding the mbaraka. It is the songs in the rituals that maintain life on Earth; the centrality of music and dance in the rituals of all these cosmologies, Amerindian and African, is undeniable and probably contributes to the exchanges established between them. A strong theme that has appeared in the reading is that of intercommunication between blacks and indigenous peoples since the beginning.

The indigenous groups as we know them today, are all fusions of many others that came together in situations of depopulation caused by epidemics and other disturbances in the colonial process. We can look for the history of these formations in rituals, songs and music, which are the preferential languages with which these questions are addressed by these people (Bastos 2013, and others). In recent years efforts have been made to approximate these universes, with the analysis remaining conceptually closer to what the practitioners are saying. There is a crossing; relationships are activated.

I conclude with a brief questioning about one of the differences most often mentioned as a mark between the indigenous world and the African world in religious terms. This involves possession. While in the African universe there is trance and a loss of consciousness (Birman 1985, among others), in the Amerindian case the most common element is the vision and the hearing of the entities in dialogue. For example, in the words of the Kaiová songs that I analyzed, there was a constant interchange of pronouns - at times it was the shaman who sang, at times it was the divine beings, at times everyone together, in dialogue, but without mentioning possession. However, in the research of my colleague Juliana Almeida, who works with the Enawene Nawe, an indigenous people from the southern Amazon who speak a language from the Arauaque family, she observes that they refer to spirits that come and take the dancer, recalling what she describes as possession (Almeida 2014, personal communication). What we must always keep in mind is that Indigenous peoples and their practices are never a monolithic block, shamanistic practices are quite varied among the different peoples. 
Only with greater knowledge about indigenous shamanisms and the development of studies that are not based on static a priori concepts about the origins of this or that element can we advance in understanding these relations. This article is a window that I'm opening to look at Afro-Brazilian religions in Manaus, focusing on the relations between practitioners and entities. In future research, I plan to conduct an ethnography that details musical and corporeal aspects of these performance rituals.

\section{Works Cited}

Anjos, José C. A filosofia política da religiosidade afro-brasileira. Debates do NER, ano 9, n. 13, pp. 77-96. 2008.

Barbosa Neto, Edgar R. 'O batuque e a linha cruzada: variações sobre os sistemas etnolitúrgicos afro-brasileiros’. 36o Encontro Anual da ANPOCS, Águas de Lindóia, SP, 2012. Acesso em 20 jan 2014

http://portal.anpocs.org/portal/index.php?option=com_docman\&task=doc_view\&gid= 8101\&Itemid $=217$.

Bastide, Roger. Estudos afro-brasileiros. São Paulo: Perspectiva. 1983.

Bastos, Rafael J. M. A Festa da Jaguatirica uma partitura crítico-interpretativa. Florianópolis: Ed. da UFSC/Coleção Brasil Plural. 2013.

Birman, Patrícia. O que é umbanda? São Paulo: Brasiliense. 1985.

Boyer, Véronique. O Pajé e o caboclo: de homem a entidade. Mana 5(1):29-56, 1999.

Ferreti, Mundicarmo. Pajelança e cultos afro brasileiros em terreiros maranhenses. Revista Pós Ciências Sociais. v. 8 n. 16 São Luis/MA, 2011.

Guimarães, Maria Beatriz L. A Experiência Religiosa como prática de terapêutica: estudo de caso de um terreiro de Umbanda com Santo Daime. Revista Mediações, Londrina, v. 11, n 2, pp 45-64, jul/dez. 2006.

Montardo, Deise Lucy O. Através do Mbaraka: música, dança e xamanismo guarani. São Paulo: EDUSP. 2009.

Mott, Yoshiko T. Caridade e demanda: um estudo de acusação e conflito na Umbanda de Marília. Dissertação de Mestrado. Campinas: Unicamp. 1976.

Oliveira, José Henrique Motta. Caboclo Angélico "baixa” no kardecismo para "anunciar" a Umbanda. Disponível em http://www.abhr.org.br/wpcontent/uploads/2008/12/oliveira-jose-henrique.pdf . 2008. Acesso em 10 de janeiro de 2014.

Pompa, Cristina. Religião como Tradução: missionários, Tupi e “Tapuia” no Brasil colonial. Bauru, SP: EDUSC, 2003.

Prandi. Reginaldo. A dança dos caboclos uma síntese do Brasil segundo os terreiros afrobrasileiros. Disponível em:

http://www.fflch.usp.br/sociologia/prandi/dancacab.rtf, p.4. Acesso em: 20 jan 2014.

Silva, Marina Barbosa e. "As religiões afro-brasileiras e a intolerância religiosa em Porto Alegre: uma luta pela legitimidade da herança africana”. XI Congresso Luso Afro Brasileiro de Ciências Sociais. Salvador: UFBA. 2011.

Souza Filho, Ademir. O. \& MONTARDO, Deise Lucy. Plano de trabalho "Performance das entidades indígenas nos terreiros de Manaus”, projeto "Arte e Sociabilidades na Amazônia” (INCT Brasil Plural/Cnpq/FAPEAM/FAPESC). Relatório Técnico Parcial Pibic, Manaus: UFAM, 2013. 